\title{
Molecular targets in arthritis and recent trends in nanotherapy
}

This article was published in the following Dove Press journal:

International Journal of Nanomedicine

26 August 2015

Number of times this article has been viewed

\section{Kislay Roy \\ Rupinder Kaur Kanwar \\ Jagat Rakesh Kanwar}

Nanomedicine-Laboratory of Immunology and Molecular Biomedical Research (NLIMBR), Centre for Molecular and Medical Research (C-MMR), Strategic Research Centre, School of Medicine (SoM), Faculty of Health, Deakin University, Waurn Ponds, VIC, Australia
Correspondence: Jagat Rakesh Kanwar Nanomedicine-Laboratory of Immunology and Molecular Biomedical Research (NLIMBR), Centre for Molecular and Medical Research (C-MMR), School of Medicine (SoM), Faculty of Health, Deakin University, 75 Pigdons Road, Waurn Ponds, VIC 3217, Australia

Tel +6I 35227 | | 48

Fax +6I 352273402

Email jagat.kanwar@deakin.edu.au
Abstract: Due to its severity and increasing epidemiology, arthritis needs no description. There are various forms of arthritis most of which are disabling, very painful, and common. In spite of breakthroughs in the field of drug discovery, there is no cure for arthritis that can eliminate the disease permanently and ease the pain. The present review focuses on some of the most successful drugs in arthritis therapy and their side effects. Potential new targets in arthritis therapy such as interleukin-1 $\beta$, interleukin-17A, tumor necrosis factor alpha, osteopontin, and several others have been discussed here, which can lead to refinement of current therapeutic modalities. Mechanisms for different forms of arthritis have been discussed along with the molecules that act as potential biomarkers for arthritis. Due to the difficulty in monitoring the disease progression to detect the advanced manifestations of the diseases, drug-induced cytotoxicity, and problems with drug delivery; nanoparticle therapy has gained the attention of the researchers. The unique properties of nanoparticles make them highly attractive for the design of novel therapeutics or diagnostic agents for arthritis. The review also focuses on the recent trends in nanoformulation development used for arthritis therapy. This review is, therefore, important because it describes the relevance and need for more arthritis research, it brings forth a critical discussion of successful drugs in arthritis and analyses the key molecular targets. The review also identifies several knowledge gaps in the published research so far along with the proposal of new ideas and future directions in arthritis therapy.

Keywords: osteoarthritis, rheumatoid arthritis, interleukin, osteopontin, nanoparticle, bovine lactoferrin

\section{Introduction}

\section{Arthritis}

Arthritis is an umbrella term for several joint disorders that involves inflammation of one or more joints or the musculoskeletal system. In Australia, disability and chronic pain are majorly caused by arthritis that has affected 3.85 million Australians. With the increase in the aging population, the number of people with arthritis is also growing; hence, the current trends suggest that, by 2050, seven million Australians will suffer from some form of arthritis (http://www.arthritisaustralia.com.au). It was also estimated that 15\% (40 million) of Americans had some form of arthritis in 1995 and an estimated $18.2 \%$ (59.4 million) will be affected by the year $2020 .{ }^{1}$ There are over 150 types of rheumatic and musculoskeletal disorders categorized under arthritis; however, the most common form of arthritis is osteoarthritis (OA). In developed countries, OA is among the ten most disabling diseases. Worldwide statistics shows that symptomatic OA will develop in $9.6 \%$ of men and $18 \%$ of women aged over 60 years (http://www.who.int/). Other arthritis forms that lead to major health burden globally are rheumatoid arthritis (RA), psoriatic arthritis, lupus, and infectious arthritis. Globally, of the 291 conditions 
studied, RA was ranked as the 42nd highest contributor to global disability, just below malaria and just above iodine deficiency. $^{2}$

\section{Available treatments for arthritis}

There is no standard treatment for arthritis available so far. The treatment strategy employed includes immunosuppressive drugs that have several side effects. Tofacitinib, methotrexate (MTX), leflunomide, and hydroxychloroquine have been commonly used so far for the arthritis treatment. A Janus Kinase (JAK) inhibitor named tofacitinib (a small molecule) has been used for the treatment of RA. The mechanism by which this inhibitor functions is by blocking the JAK signaling through JAK 3 and JAK 1 that are heterodimeric receptors of JAK. Blocking of these receptors (JAK1 and JAK3) by tofacitinib further leads to blocking of several cytokines such as interleukins (ILs) 2, 4, 7, 9, and 21, which contribute significantly in modulating immune response. ${ }^{3}$ It has been reported that tofacitinib involves serious infections (cellulitis [5-mg group] and liver abscess, bronchitis, tuberculous pleural effusion, and pyelonephritis [10-mg group]). ${ }^{4}$ Tofacitinib is administered orally at $50 \mathrm{mg} / \mathrm{kg}^{5}$ or using osmotic minipump infusion at doses of $1.5,5$, and $15 \mathrm{mg} / \mathrm{kg}$. ${ }^{6}$

Competitive inhibition of dihydrofolate reductase that plays an important role in tetrahydrofolate synthesis can be achieved by MTX. ${ }^{7}$ Other multiple mechanisms are involved apart from the inhibition of dihydrofolate reductase that include inhibition of 1) enzymes that play a role in purine metabolism ${ }^{8}$ and 2) binding of IL-1 beta to its cell-surface receptor. ${ }^{9}$ Some of the commonly associated side effects of using MTX are ulcerative stomatitis, liver damage (hepatotoxicity), low count of white blood cells, which further lead to nausea, abdominal pain, fever, fatigue, infection, dizziness, and acute pneumonitis. In a few cases, it rarely leads to pulmonary fibrosis. ${ }^{10}$ MTX can be administered intraperitoneally at $0.01 \mathrm{~mL} / \mathrm{g}$ in $7 \%$ sodium bicarbonate, ${ }^{11}$ intraperitoneal injections $(1 \mathrm{~mL})(0.05-0.5 \mathrm{mg} / \mathrm{kg})$ in normal saline $(0.9 \%),{ }^{12}$ intramuscularly at $0.3 \mathrm{mg} / \mathrm{kg}$ twice a week, ${ }^{13}$ by oral gavage at $0.2 \mathrm{mg} / \mathrm{kg} / \mathrm{day},{ }^{14}$ or mixed with powdered food at $0.2 \mathrm{mg} / \mathrm{kg} / \mathrm{day} .{ }^{15}$ Tofacitinib has been proven to be functionally, clinically, and radiographically more effective than MTX in treating patients with RA. ${ }^{5}$

Leflunomide (brand names: Arabloc, Arava, Lunava, Repso) is an immunosuppressive disease-modifying antirheumatic drug. ${ }^{16}$ Inhibition of mitochondrial enzyme named dihydroorotate dehydrogenase that is involved in de novo pyrimidine synthesis is the primary mode by which leflunomide acts as an immunomodulatory drug. This inhibits the reproduction of any rapidly dividing cells including the lymphocytes. However, like every other drug some doselimiting side effects are associated with the drug, such as lung disease, liver damage, and finally immunosuppression. ${ }^{17}$

Hydroxychloroquine is an antimalarial drug. ${ }^{18}$ The mechanism by which antimalarial drug chloroquine and hydroxychloroquine act on cells is by increasing the $\mathrm{pH}$ within intracellular vacuoles that alter the degradation of protein in lysosomes by acidic hydrolases, this does not allow the assembly of macromolecules in the endosomes. Another way by which these drugs act is by post-translational modification of the proteins in Golgi apparatus. Interference with the "antigen processing" in antigen-presenting cells and macrophages is the proposed mechanism for attributing antirheumatic properties to the above-mentioned drugs. Acidic cytoplasmic compartments are required for the antigenic protein to be digested and for the peptides to assemble with the alpha and beta chains of major histocompatibility class (MHC) II proteins. For the antigens to be processed and digested in order for it to assemble with the alpha and beta chains of the MHC class II proteins, acidic $\mathrm{pH}$ in the cytoplasmic components is essential. Enabling the formation of the virus peptide-MHC complex will stop the production of $\mathrm{CD}^{+} \mathrm{T}$ cells hence avoiding an immune response against autoantigenic peptides and inhibiting this complex formation should be an essential feature of the antimalarial. ${ }^{19}$ The most commonly associated effects of antimalarial drugs are usually mild nausea and diarrhea with occasional stomach cramps.

\section{Key molecular targets in arthritis}

There are several reports stating various mechanisms for different forms of arthritis. Some key molecules have been identified and are being used as the targets by the upcoming antiarthritic therapies (Table 1).

\section{Cytokines}

Cytokines have been indicated to play a critical role in the pathological process of development of OA. IL- $1 \beta$ is one such cytokine that is responsible for the cartilage matrix degradation and destruction of the articular cartilage. IL-1 $\beta$ inhibits the type II collagen synthesis of hyaline cartilage that changes and destroys the surrounding environment of cartilage cells and leads to variations in the structure of cartilage protein. Studies have reported that IL-1 $\beta$ content in OA patient's knee joint synovial fluid (SF) is higher than healthy people and IL-1 $\beta$ content is significantly positive correlated with patient's knee joint OA score. Therefore, IL-1 $\beta$ content in knee joint SF can be used not only as a reference index in the diagnosis of OA, but also as an important therapeutic 
Table I Key molecular targets and their role in arthritis

\begin{tabular}{|c|c|c|c|c|}
\hline S no & Key molecular targets & Role & Occurrence & References \\
\hline $\mathrm{I}$ & IL-I $\beta$ & Inhibits synthesis of hyaline cartilage & Knee joint and synovial fluid & 20 \\
\hline 2 & Cathepsin-B & Cleaves aggrecan and progression of $\mathrm{OA}$ & $\begin{array}{l}\text { During the early degenerative } \\
\text { phase of } O A \text { in synovial tissue }\end{array}$ & 21 \\
\hline 3 & MMP-3 & Progression of OA pathogenesis & Synovial tissue & 22 \\
\hline 4 & IL-6 & $\begin{array}{l}\text { Differentiation of } \mathrm{T} \text { cells in } \mathrm{TH}-\mathrm{I}, \mathrm{TH}-2 \text {, } \\
\text { and } \mathrm{TH}-17 \text { cells }\end{array}$ & Synovial T cells & 25 \\
\hline 5 & IL-I7A & $\begin{array}{l}\text { Activation and expression of pro- } \\
\text { inflammatory cytokines IL-I, IL-6, and } \\
\text { IL-8 }\end{array}$ & Synovial fluids & $27-29$ \\
\hline 6 & $\begin{array}{l}\text { Tumor necrosis factor } \\
\text { (TNF)- } \alpha\end{array}$ & $\begin{array}{l}\text { Secretion of IL-6, IL-8, granulocyte-macro- } \\
\text { phage colony-stimulating factor (GM-CSF), } \\
\text { and matrix metalloproteinases (MMPs) }\end{array}$ & Synovial fluids & 30 \\
\hline 7 & $\begin{array}{l}\text { Urokinase-type } \\
\text { plasminogen (uPA) }\end{array}$ & $\begin{array}{l}\text { uPA/uPAR signaling promotes the } \\
\text { inflammatory joint disease }\end{array}$ & Synovial cells & 31 \\
\hline 8 & Oncostatin M & $\begin{array}{l}\text { Potent pro-inflammatory properties in } \\
\text { synergy with IL-I to promote articular } \\
\text { cartilage damage }\end{array}$ & Synovial fibroblasts & 32 \\
\hline 9 & Type I collagen & $\begin{array}{l}\text { Induction of osteoblastic differentiation } \\
\text { of the bone marrow cells }\end{array}$ & Bone & 34 \\
\hline 10 & Type II collagen & Maintain the integrity of cartilage & Cartilage & 35 \\
\hline II & Aggrecan & Maintain the integrity of cartilage & Synovium & 37 \\
\hline 12 & Prostaglandin (PG) EI & Potent stimulator of bone resorption & Osteocytes & 43 \\
\hline 13 & $\begin{array}{l}\text { Forkhead box P3 } \\
\text { (Foxp3)+ } \mathrm{T} \text { cells }\end{array}$ & $\begin{array}{l}\text { Balance between the regulatory } T \text { (Treg) } \\
\text { cells and the } T \text { helper }(\mathrm{TH}-\mathrm{I} 7) \text { cells }\end{array}$ & Synovium & 44 \\
\hline 14 & Osteopontin (OPN) & $\begin{array}{l}\text { Stimulates cell adhesion, migration, } \\
\text { invasion, and specific signaling function }\end{array}$ & $\begin{array}{l}\text { Activated macrophages, } \\
\text { leukocytes, and activated } \\
\text { T lymphocytes, extracellular } \\
\text { fluids, sites of inflammation, and } \\
\text { in ECM of mineralized tissues }\end{array}$ & $53,59,68-71$ \\
\hline
\end{tabular}

Abbreviations: ECM, extracellular matrix; IL, interleukin; OA, osteoarthritis; uPAR, uPA receptor.

target for treatment of OA. ${ }^{20}$ Other important cytokines involved in $\mathrm{OA}$ include transforming growth factor $\beta$ and cathepsin-B. Cathepsin-B is upregulated in synovial tissue during the early degenerative phase of $\mathrm{OA}$ and can cleave aggrecan at a site near to that of matrix metalloproteinase (MMP)-3, which is responsible for progression of OA pathogenesis. ${ }^{21}$

MMPs are also known to play a major role in progression of both OA and RA. In a study, levels of MMP-1, $-2,-3,-7,-8,-9$, and -13 were studied from 97 patients with RA and 103 patients with $\mathrm{OA}$. The results revealed that levels of MMP-1, MMP-2, MMP-3, MMP-8, and MMP-9 were higher in RA patients than in OA. Moreover, among all the MMPs being tested, MMP-3 levels were found to be extremely high. ${ }^{22}$ The early degenerative phase of $\mathrm{OA}$ is usually characterized by the upregulation of cathepsin-B that can cleave aggrecan at a site near to that of MMP3, which is responsible for the progression of OA pathogenesis. Critical pathways that have been found to be related with OA include the tyrosine metabolism pathway, Wnt signaling pathway, and the circadian rhythm pathway. Microarray analysis was performed to identify the differentially expressed genes between OA patients and healthy individuals, and the results revealed that differentially expressed genes such as the platelet-derived growth factor receptor, beta polypeptide, interferon gamma (IFN- $\gamma$ ), early growth response 1, Fas ligand (tumor necrosis factor [TNF] superfamily, member 6), and $\mathrm{H} 3$ histone, family 3B (H3.3B) could be used as potential targets for $\mathrm{OA}$ diagnosis and treatment. ${ }^{23}$ Recent studies have shown that hyaluronic acid (HA) derivatives have the potential to reduce the expression of proteolytic enzymes responsible for cartilage degradation in OA such as MMP-1, MMP-13, disintegrin, and IL-6. HA derivatives have also shown to increase the secretion of anti-inflammatory cytokines such as IL-10. The hexadecylamide derivative of HA has shown the potential to suppress the inflammatory response induced by calcium pyro-phosphate crystals and reduces the secretion of IL-1 $\beta$ and IL-8. It is also well known that HA binds with high affinity to CD44 leading to the inhibition of NF- $\mathrm{KB}$ secretion. ${ }^{20,24}$

Pathogenesis of RA involves CD4 ${ }^{+} \mathrm{T}$ cells, B cells, and monocytes. IL-6 is known to facilitate the differentiation of 
T cells into effector T cells (TH1, TH2, and TH-17 cells) or regulatory $\mathrm{T}$ (Treg) cells..$^{25}$ Cytokines produced by these synovial T cells include TNF-alpha (TNF- $\alpha$ ), IFN- $\gamma$, and IL-17A. The IL-17A production is restricted to a specific $\mathrm{T}$ helper (Th) cell subpopulation, referred to as TH-17. The IL-17A expression is confined to memory $\mathrm{T}$ cells expressing the transcription factor RAR-related orphan receptor-C and the chemokine receptor CCR6. ${ }^{26}$ In patients with RA, CCR $6^{+}$Th cells have been found in the inflamed synovium, and increased proportions of peripheral blood CCR $6^{+}$Th cells have been found in patients with early RA. Studies have also shown that the pathogenic signature is not confined to cells producing high levels of IL-17A, but that even CCR6 $6^{+}$Th cell populations producing low amounts of IL-17A display a pathogenic signature and activity. ${ }^{27}$ Therefore, the cell populations producing IL-17 can form an important target for RA therapy.

IL-17 is a type I transmembrane glycoprotein with a molecular mass of $120 \mathrm{kDa}$ and is known to play a central role in the inflammatory response in RA. ${ }^{28}$ IL-17 mediated transduction leads to further activation and expression of pro-inflammatory cytokines such as IL-1, IL-6, and IL-8 that contribute to the inflammation. A strong correlation between the expression of IL-17 and IL-15 was observed in the SFs of RA patients but not in OA patients. It was revealed that IL-15 triggered the secretion of IL-17 from peripheral blood mononuclear cells in SFs/joints of RA patients. ${ }^{29}$ Studies have also reported that TNF- $\alpha$ and IL-17 show additive/ synergistic effects in promoting the secretion of IL-6, IL-8, granulocyte colony-stimulating factor and MMPs, all of which play a major role in progress of inflammation and cartilage degradation. A therapy targeting a single cytokine is not very effective as a number of molecules play a role in arthritis progression leading to the development of inflammation and bone and cartilage destruction in arthritis. Recently, a study with bispecific anti-TNF- $\alpha /$ IL-17 antibody showed that inhibition of both TNF- $\alpha$ and IL-17 showed superior efficacy than a single therapy in inhibiting cytokine, chemokine, and MMPs and in blocking tissue destruction in arthritis. ${ }^{30}$

Other cytokines that play a fundamental role in the mechanisms mediating inflammatory joint disease pathogenesis have also been identified. A study indicated a near complete amelioration of joint disease in urokinase-type plasminogen (uPA)-deficient collagen-induced arthritis (CIA) mice, which was mainly due to significantly reduced local mRNA levels of key inflammatory mediators (eg, TNF- $\alpha$, IL- $1 \beta$, and IL-6) in these animals. Their findings reveal that cell-surface associated uPA/uPA receptor-mediated proteolysis and/or uPA receptor-mediated signaling events from bone marrowderived cells are important in promoting the inflammatory joint disease, and that inhibition of this key proteolytic/signaling system may provide an innovative therapeutic strategy to prevent arthritis. ${ }^{31}$ Oncostatin M (OSM) is another cytokine, which has emerged as a powerful mediator of RA. It is known to have potent pro-inflammatory properties in mice and synergy with IL-1 to promote articular cartilage damage. Apart from these, OSM induced an increase in P-selectin in endothelial cells, stimulates uPA activity in synovial fibroblasts, and is also a powerful inducer of IL-6 from endothelial cells. Based on these evidence, OSM also forms an important therapeutic target for targeting arthritis. ${ }^{32}$

\section{Proteins}

Several proteins are known to play a major role in regulation of OA. These include type I collagen in the bone, type II collagen, MMPs and aggrecan in the cartilage and type III collagen in the synovium. ${ }^{33}$ It is known that type I collagen is responsible for the induction of osteoblastic differentiation of the bone marrow cells. The type I collagen interacts with the $\alpha 2 \beta 1$ integrin receptors and mediates the extracellular signaling. Studies have shown that inhibition of both type I collagen by a peptide and $\alpha 2 \beta 1$ integrin by an anti- $\alpha 2$ antibody suppressed the expression of osteoblastic phenotypes. ${ }^{34}$ The type II collagen on the other hand is known to maintain the integrity of cartilage by forming a fibrillar network. Damage to this network has been known to cause OA. ${ }^{35}$ It is reported that collagenases produced by the chondrocytes are involved in the cleavage and denaturation of type II collagen, which leads to an increase in OA. ${ }^{36}$ Another major protein that regulates cartilage degradation is aggrecan. A study suggested that aggrecan is majorly degraded due to the action of specific proteinases aggrecanase- 1 and aggrecanase- 2 . They generated expression plasmid vectors of shRNA targeting aggrecanase- 1 and aggrecanase- 2 and transfected them into rat chondrocyte cells. Their findings revealed that inhibition of both aggrecanase-1 and aggrecanase- 2 by RNA interference could mitigate aggrecan degradation without affecting the normal functioning of the cells. ${ }^{37}$ Meanwhile, another study reported that aggrecanase inhibition by lentivirusmediated RNA interference can lead to chondrocyte proliferation and an increase in aggrecan and type II collagen. ${ }^{38}$ Thus, these proteins can be targeted or regulated or used to control the progression of arthritis. One such attempt was made where nanoparticles (NPs) that mimic the size, glycosaminoglycan composition, and growth factor binding and 
stabilization of aggrecan were used in bone marrow stromal cells and delivered fibroblast growth factor-2. ${ }^{39}$

\section{Inflammatory cells}

It is known that osteoclasts lead to bone destruction in arthritis; however, recent study has shown that osteoclast progenitors and stromal cells that are rheumatoid synovial cells support their differentiation, indicating their role in osteoclastogenesis in synovium which could be a new mechanism of bone destruction in RA. ${ }^{40}$ In order to determine the most efficient diagnostic marker for identification of changes in the bone mineral density (BMD), a study was conducted with serum and urine samples from 232 RA patients. The assay contained markers like procollagen I carboxyterminal propeptide and skeletal alkaline phosphatase from serum and pyridinoline and deoxypyridinoline corrected for creatinine in urine. Plasma samples were also tested for IL-1 and IL-6. Urinary markers best identified change in BMD, however, CRP was most effective overall. This provides a rational approach for selecting and treating patients with RA to reduce the long-term risk of osteoporotic mediated fractures. ${ }^{41}$ Apart from the muscular activity, reductions in total body potassium are also correlated with changes in BMD leading to disease severity with the production of TNF- $\alpha{ }^{42}$ Apart from these processes, inflammatory cytokine prostaglandin E1 has also been identified as a potent stimulator of bone resorption. ${ }^{43}$

It has been reported that an imbalance between the $\mathrm{T}$ regulatory cells and the T helper cells (TH-17) often leads to development of autoimmune disorders. Studies have reported that the forkhead box P3 (Foxp3) ${ }^{+} \mathrm{T}$ cells which give rise to $\mathrm{TH}-17$ cells play a major role in the pathogenesis of autoimmune arthritis. ${ }^{44}$ During arthritis, the CD25(low) Foxp $3^{+} \mathrm{CD} 4^{+} \mathrm{T}$ cells lose the Foxp 3 expression and are called as exFoxp3 cells and further undergo differentiation to give rise to TH-17 cells. This trans-differentiation is mediated by the IL-6 produced by the synovial fibroblast cells. The severity of the disease has been directly correlated with Foxp3 loss (Figure 1). ${ }^{45}$ There have been several inventions and strategies to target the Foxp $3^{+}$Treg cells or to inhibit the $\mathrm{T}$ regulatory activity. Some of these include targeting Treg

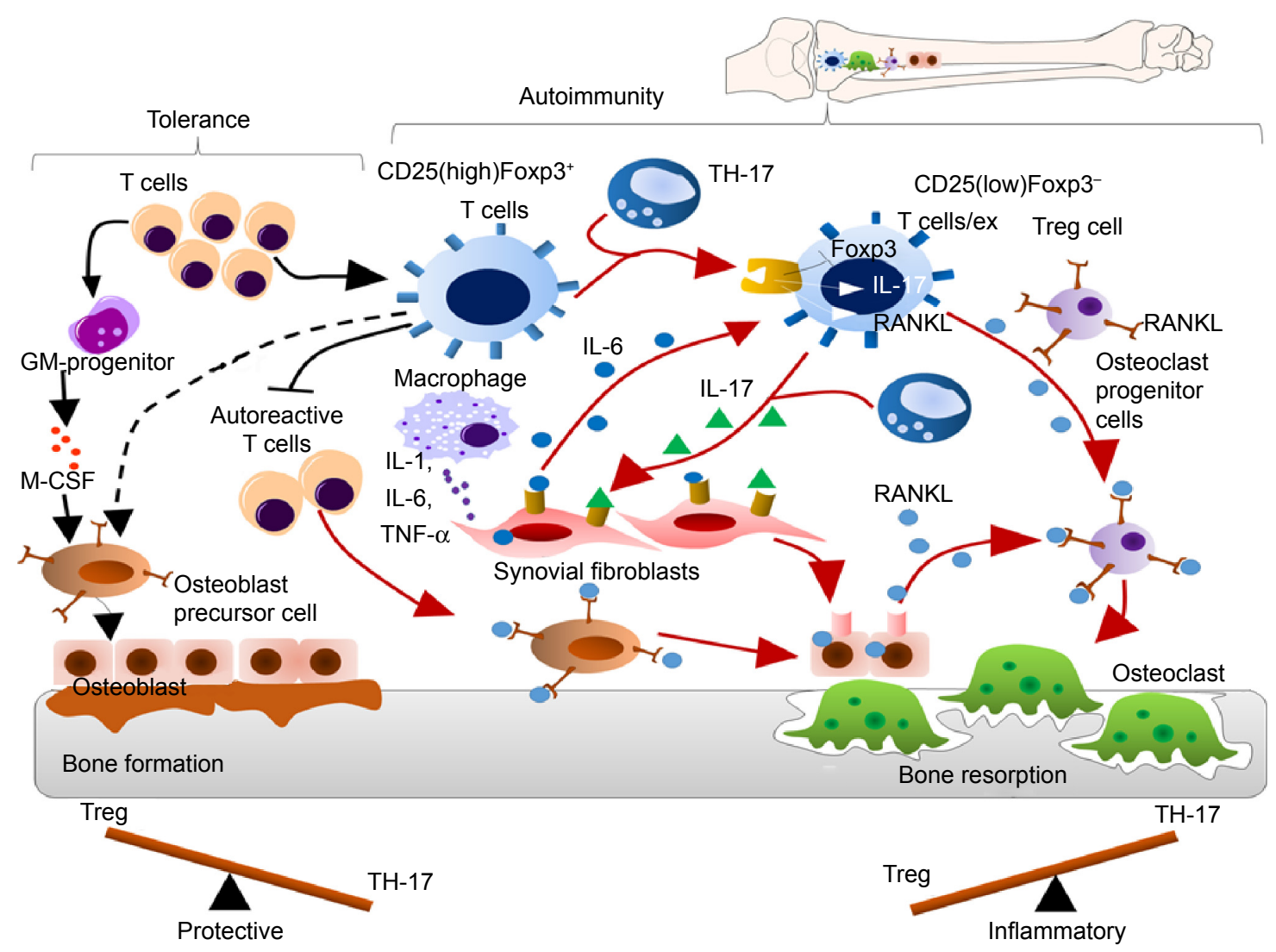

Figure I The mechanism of balance between tolerance and autoimmunity at the site of arthritic joint inflammation.

Notes: During autoimmune arthritis, the naturally occurring CD25(high)Foxp $3^{+} \mathrm{T}$ regulatory cells convert into CD25(low)Foxp $3^{-} \mathrm{T}$ regulatory cells by losing Foxp3 expression. IL- 6 and IL- 17 secreted by the synovial fibroblasts induce the conversion of this subset of T regulatory cells into pathogenic TH- 17 cells. Like synovial fibroblasts and osteoblasts, TH-I7 cells derived from Foxp3+ T cells can produce high levels of RANKL, which directly promote osteoclastogenesis/bone resorption/destruction. Abbreviations: GM, granulocyte-macrophage; M-CSF, macrophage colony-stimulating factor; IL, interleukin; TH, T helper; TNF- $\alpha$, tumor necrosis factor alpha. 
cells via vaccination with immunogenic peptides from the Foxp3 transcription factor that has been proven to be an effective method for reducing the Treg cells, ${ }^{46}$ peptide inhibitor of transforming growth factor $\beta$ that leads to inhibition of the $\mathrm{T}$ regulatory activity, ${ }^{47}$ a 15 -mer-synthetic peptide that has the ability to enter into the cells, binds with Foxp3, and inhibits the nuclear translocation of Foxp3 therefore impairing the $\mathrm{T}$ regulatory activity ${ }^{48}$ and by targeting Sirtuin 1 which is a class III histone/protein deacetylase and inhibits the $\mathrm{T}$ regulatory functions. ${ }^{49}$

It is also reported that mast cells play a critical role in generation of inflammation within the joint. During the normal stage mast cells are scattered around blood vessels and nerves and form only up to $3 \%$ of all cells in the synovium, ${ }^{50}$ while during RA the population of mast cells is reported to increase up to $5 \%$ of total synovial cells ${ }^{51}$ and lead to production of TNF- $\alpha$ and IL-17. ${ }^{52}$

\section{Role of osteopontin in arthritis}

Osteopontin (OPN) is a phosphorylated extracellular matrix (ECM) glycoprotein secreted by activated macrophages, leukocytes, and activated $\mathrm{T}$ lymphocytes, and present in extracellular fluids, at sites of inflammation, and in the ECM of mineralized tissues. OPN is known to interact with a variety of cell-surface receptors, for example, $\alpha v \beta 3$, $\alpha v \beta 5, \alpha v \beta 1, \alpha 4 \beta 1, \alpha 8 \beta 1$, and $\alpha 9 \beta 1$ integrins, as well as
CD44. ${ }^{53}$ Cell adhesion, invasion, migration, and other specific signaling functions are dependent on the binding of OPN to the above-mentioned cell-surface receptors (Figure 2).${ }^{54}$ The most important integrin-binding site in OPN is the arginine-glycine-aspartate (RGD) integrinbinding motif, which is necessary for the adherence of many cell types to OPN. ${ }^{55}$ The expression of OPN in adults is mainly restricted to the kidney, bone, and epithelial linings of organs. It is also secreted in milk, blood, and urine (bodily fluids). ${ }^{56}$ In comparison with its restricted allocation in the normal tissue, OPN is markedly upregulated at sites of inflammation and tissue remodeling. ${ }^{57,58}$ OPN exists in two forms, one as a component of the ECM and other as a soluble cytokine. The main role of OPN in physiological processes includes its regulation of biomineralization in the bone tissues and its ability to reduce the growth and aggregation of calcium crystals in epithelial tissues. ${ }^{59}$ Thus, in spite of the criticalness and availability of relevant information regarding OPN, very little therapeutics against arthritis target OPN.

OPN concentrations in the plasma have been clinically correlated with chronic inflammatory diseases such as Crohn's disease, cancer, atherosclerosis, aortic abdominal aneurysms, and autoimmune diseases including lupus, multiple sclerosis, and RA. ${ }^{60} \mathrm{OPN}$ is a known T-lymphocyte suppressor factor and is reported to enhance the B-lymphocyte

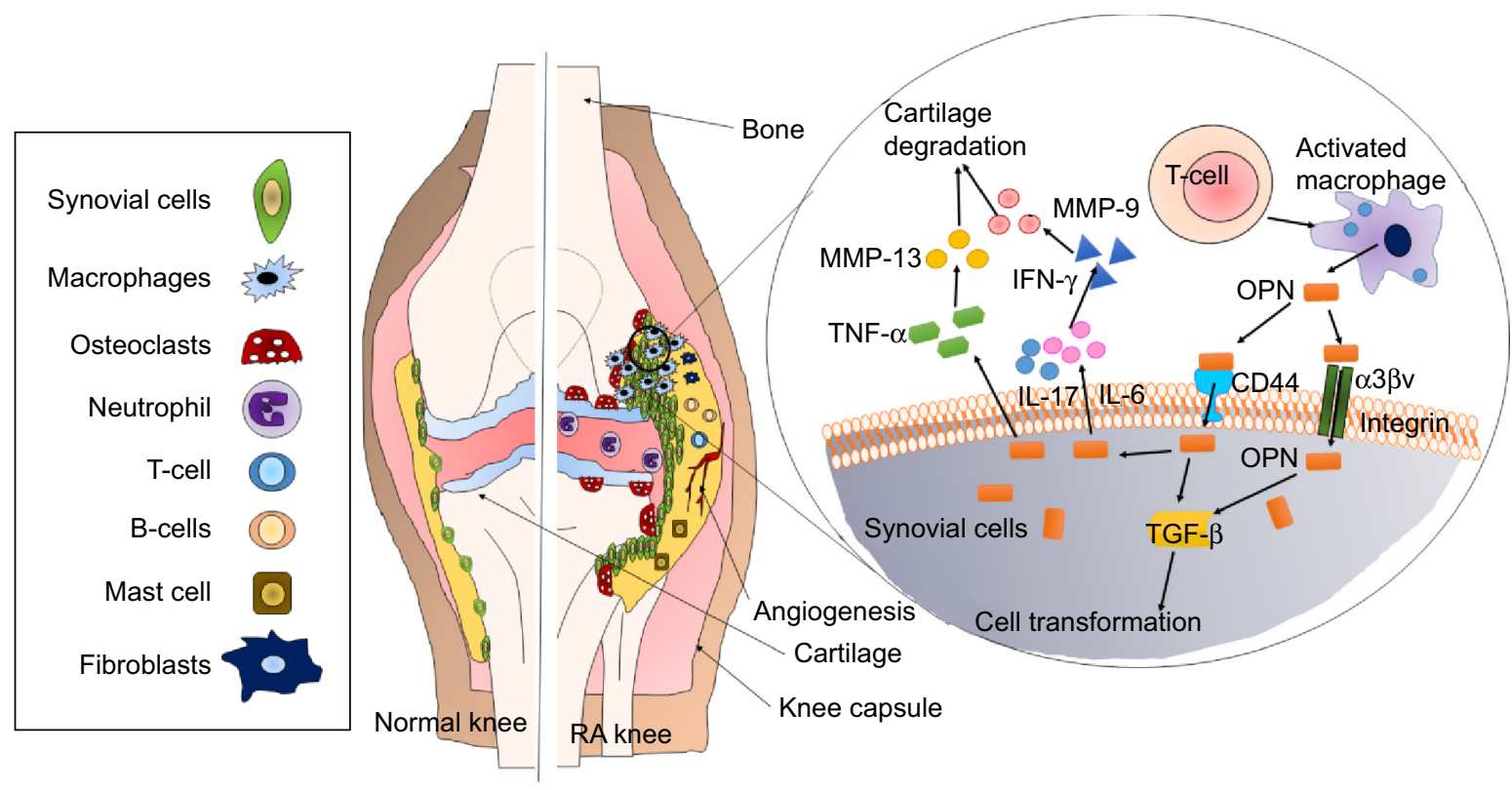

Figure 2 Role and importance of osteopontin in arthritis.

Notes: Osteopontin (OPN) is highly expressed in the synovial fluid and in bones, which leads to production of pro-inflammatory cytokines and attachment of osteoclasts to the bone matrix. OPN is known to interact with CD44 and integrin receptors on cell membrane leading to activation of TGF- $\beta$ signaling and further activation of proinflammatory cytokines such as IL- I7, IL-6, and TNF- $\alpha$. Pro-inflammatory cytokines lead to cartilage degradation.

Abbreviations: IL, interleukin; MMP, matrix metalloproteinase; TGF- $\beta$, transforming growth factor $\beta$; TNF- $\alpha$, tumor necrosis factor alpha. 
Ig production and proliferation. In addition, OPN also acts as a pro-inflammatory molecule becoming an important cytokine mediating the Th1 immunity further regulating the immune system at various levels OPN enhances migration of inflammatory cells toward an injury site and retains cells at the site serving as both a chemotactic molecule and an adhesive protein. The level of OPN was found to significantly correlate with IL-17 production and the frequency of TH-17 cells in the SF of RA patients. ${ }^{61}$ Immune response during bacterial and viral infections is centrally regulated by OPN that activates $\mathrm{T}$ cells and macrophage responses. OPN has also been reported to modulate dendritic cell responses and neutrophil chemotaxis. ${ }^{62}$

Attachment to the cartilage by the invasive growth of synovial tissue mediated joint destruction in RA. The expression of OPN mRNA and protein in RA patients revealed that OPN was overexpressed in the synovial lining and sub-lining layer and at the interface of cartilage and invading synovium. The role of OPN has also been studied as a marker that not only as a synovial lining layer at the site of cartilage invasion but also mediates the attachment of synovial fibroblasts to cartilage at the sites of invasion. It also contributes to matrix degradation in RA. ${ }^{63}$ The presence of OPN and its expression in the cartilage and synovial is associated with destruction of the surface structures of the joint, joint swelling, and loss of proteoglycan content in the articular cartilage in mice. ${ }^{64}$ In contrast, OPN deficiency was shown to prevent the mice from such surface destruction, loss of proteoglycan in the articular joint cartilage, and swelling of the joints. Hence, OPN promotes angiogenesis and induces apoptosis in chondrocytes that plays a critical role in the destruction of joint cartilage in RA mice model. ${ }^{64} \mathrm{OA}$ is the most common form of arthritis (joint disease), which mainly affects elderly. Overexpression and a high level of presence of OPN in SF and articular cartilage has been found to be associated with OA progression. ${ }^{65}$ It has been reported that phosphorylation of OPN leads to activation of MMP-13 expression at both gene and protein levels in the cartilage, which has been further correlated with the cartilage degeneration. ${ }^{66}$ OPN levels in plasma and urine, measured by enzyme-linked immunosorbent assay in 119 patients with RA, were found to be highly elevated confirming that OPN levels could clearly be used as a biomarker to detect the onset of RA.${ }^{67}$ Another study involving 50 patients with knee OA and 10 healthy controls revealed that when compared with the healthy controls the OA patients had higher OPN concentration in the SF and in the articular cartilage confirming that OPN can be used as a biomarker for OA. ${ }^{68}$

\section{NP therapy in arthritis}

NPs are defined as particles that measure $1-100 \mathrm{~nm}$ in at least one dimension. Recent research has focussed on NPs in novel ways to aid in the field of medicine that include detection and treatment of diseases as their size scale is similar to that of biological molecules (eg, proteins and DNA) and structures (eg, viruses). ${ }^{69}$ Targeted delivery of drugs to specific cells and tissues is one of the major uses of engineered NPs in medicine. Recently, promising drugs such as celecoxib, diclofenac, and ibuprofen have been tested against OA and found to significantly decrease the IL-6 and TNF- $\alpha$ in the SF. Higher dosages of these non-steroidal anti-inflammatory drugs provided a greater improvement in the disease-specific quality of life advantages of patients and lower concentrations of pro-inflammatory cytokines in the SF. Inhibition of mitogen-activated protein kinases (MAPKs) was noted after non-steroidal anti-inflammatory drug treatment. ${ }^{70}$ Thus, such promising drugs can be used in forms of nanotherapy. These nanosystems have the capability to release the drug slowly in the environment; therefore, lower and reduced drug dosages are required hence avoiding the non-specific side effects of the drugs. NPs derived from some interesting biomaterials can be used as scaffolds in bone tissue engineering as they can be made to exhibits excellent biocompatibility with surrounding tissues. ${ }^{71}$ Some NPs also hold the capability to deliver poorly water soluble drugs, which is otherwise very difficult to achieve. ${ }^{72}$ The engineering of NPs can be done to specifically recognize or specifically inhibit or enhance immune responses or to completely avoid the immune system recognition. ${ }^{73}$ With the enhancement in technology, nanoscience has come up with multifunctional NPs that can be used simultaneously for imaging, diagnosis, drug delivery, and treatment. ${ }^{74}$ Due to several such benefits a number of NP systems have been used for drug delivery and therapy of arthritis (Table 2).

\section{Non-targeted nanoparticle approach in RA}

In the year 2014, over 20 research publications have reported the development of various nanocarrier (NC) systems for delivery of synthetic or natural anti-inflammatory compounds in RA model. Most of these NPs were biodegradable including chitosan (CS)-coated calcium phosphate encapsulating iron saturated bovine lactoferrin (C-CP-Fe-bLf -NCs) for delivery of Fe-bLf in in vitro inflammatory OA model and in CIA mice. Oral administration of these NCs in mice was found to be non-toxic and induced disease reversal by reducing joint inflammation and significantly inhibiting the 
Table 2 Recent trends in nanotherapy used for drugs delivery in arthritis models

\begin{tabular}{|c|c|c|c|c|}
\hline S no & Nanoparticle system & Drug/protein & Model & References \\
\hline I & $\begin{array}{l}\text { Iron saturated bovine lactoferrin } \\
\text { (C-CP-Fe-bLf -NCs) }\end{array}$ & Fe-bLf & $\begin{array}{l}\text { Collagen-induced arthritis } \\
(\mathrm{ClA}) \text { mice }\end{array}$ & 75 \\
\hline 2 & Iron saturated bovine lactoferrin & $\begin{array}{l}\text { Lakshadi Guggul (LG) } \\
\text { and Cissus quadrangularis }\end{array}$ & $\begin{array}{l}\text { Primary human chondrocytes, } \\
\mathrm{CIA} \text { mice }\end{array}$ & 76 \\
\hline 3 & Solid lipid nanoparticles (SLNs) & Curcumin & $\begin{array}{l}\text { Complete Freund's adjuvant } \\
\text { (CFA)-induced arthritis in rats }\end{array}$ & 77 \\
\hline 4 & $\begin{array}{l}\text { Glycol-split non-anticoagulant } \\
\text { heparin nanoparticles (NAHNPs) }\end{array}$ & $\begin{array}{l}\text { D-erythro-sphingosine } \\
\text { (inhibitor of the TLR- } \\
\text { induced inflammation) }\end{array}$ & $\begin{array}{l}\text { Lipopolysaccharide (LPS)-induced } \\
\text { primary mouse macrophages and } \\
\text { DC2.4 dendritic cell line. Type II } \\
\text { CIA mice }\end{array}$ & 78 \\
\hline 5 & $\begin{array}{l}\text { Hyaluronan nanoparticles } \\
\text { (HA-NPs) }\end{array}$ & $\begin{array}{l}\gamma \text {-secretase inhibitor } \\
\text { (DAPT) }\end{array}$ & $\mathrm{ClA}$ mice & 79 \\
\hline 6 & $\begin{array}{l}\text { Polysialic acid (PSA)-trimethyl } \\
\text { chitosan (TMC) NPs }\end{array}$ & $\begin{array}{l}\text { Dexamethasone (DM) } \\
\text { and methotrexate (MTX) }\end{array}$ & In vitro model of RA & 80 \\
\hline 7 & $\begin{array}{l}\text { Polyethyleneimine (PEI)- } \\
\text { superparamagnetic iron oxide } \\
\text { nanoparticles (SPION) }\end{array}$ & IL-2/IL-I5R $\beta$-siRNA & $\mathrm{ClA}$ rats & 81 \\
\hline 8 & Tranilast (TL) NPs & Tranilast & Adjuvant-induced arthritis (AA) rats & 82 \\
\hline 9 & Chitosan NPs & Anti-TNF- $\alpha$ siRNA & ClA mice & 83 \\
\hline 10 & $\begin{array}{l}\text { Thiolated glycol chitosan } \\
\text { (tGC) NPs }\end{array}$ & $\begin{array}{l}\text { Polymerized siRNA } \\
\text { targeting TNF- } \alpha\end{array}$ & CIA mice & 84 \\
\hline II & $\begin{array}{l}\text { Hybrid hyaluronic acid } \\
\text { (HA)/chitosan (CS) NPs }\end{array}$ & Plasmid DNA & In vitro model of OA & 86 \\
\hline 12 & $\begin{array}{l}\text { Chitosan-graft-polyethylenimine } \\
\text { (CP)/DNA NPs }\end{array}$ & Plasmid DNA & In vitro model of OA & 87 \\
\hline 13 & $\begin{array}{l}\text { Diacerein-loaded solid lipid } \\
\text { NPs modified with chondroitin } \\
\text { sulphate }\end{array}$ & Diacerein & $\begin{array}{l}\text { Chemically induced rat model } \\
\text { for osteoarthritis }\end{array}$ & 88 \\
\hline 14 & $\begin{array}{l}\text { Poly(lactic-co-glycolic acid) } \\
\text { (PLGA) NPs }\end{array}$ & Methotrexate & RAW 264.7 cells & 92 \\
\hline 15 & Perfluorocarbon NPs & $\begin{array}{l}\text { Lipase-labile fumagillin } \\
\text { (Fum-PD) }\end{array}$ & In vitro model of RA & 93,94 \\
\hline 16 & $\begin{array}{l}\text { Hyaluronate-gold nanoparticles } \\
\text { (HA-AuNP) }\end{array}$ & Tocilizumab & $\mathrm{ClA}$ mice & 95 \\
\hline 17 & $\begin{array}{l}\text { Theranostic gold }(\mathrm{Au}) \text { half- } \\
\text { shell NPs }\end{array}$ & Methotrexate & $\mathrm{ClA}$ mice & 96 \\
\hline 18 & PLGA NPs & STATI siRNA delivery & $\mathrm{ClA}$ mice & 97 \\
\hline
\end{tabular}

Abbreviations: IL, interleukin; OA, osteoarthritis; RA, rheumatoid arthritis; TLR, Toll-like receptor.

expression of catabolic genes, IL-1 $\beta$, nitric oxide, c-Jun N-terminal kinase, and MAPK. The C-CP-Fe-bLf -NCs showed the ability to completely dissolve the calcium pyrophosphate crystals in mice joints indicating their therapeutic ability to be used as a treatment for chronic inflammatory rheumatic diseases such as OA. ${ }^{75}$ The same NC system was also used to deliver Lakshadi Guggul and Cissus quadrangularis both in vitro in primary human chondrocytes and in vivo in mice with CIA. Lakshadi Guggul NCs revealed cartilage regenerative activity, were non-toxic to mice, reduced joint swelling and paw volume, and inhibited gene expression of MMPs and cytokines. ${ }^{76}$ Solid lipid nanoparticles (SLNs) have been used for delivery of curcumin for the treatment of RA in complete Freund's adjuvant-induced arthritis in rats. ${ }^{77}$ It was revealed that these NPs showed a dose-dependent reduction in the various symptoms of arthritis, improved biochemical markers, and preserved radiological alterations in joints of arthritic rats. In an experimental arthritis model, the glycolsplit non-anticoagulant heparin NPs were used for delivery of D-erythro-sphingosine (inhibitor of the Toll-like receptorinduced inflammation). ${ }^{78}$ In lipopolysaccharide induced primary mouse macrophages and DC2.4 dendritic cell line, non-anticoagulant heparin NPs inhibited the production of pro-inflammatory cytokines such as TNF- $\alpha$, IL-6, and IL-1 $\beta$ significantly. When were administered to type II CIA mice by intraarticular injections once a day, they led to a decrease in arthritis score and footpad swelling. It was also observed that the levels of pro-inflammatory cytokines - eg, TNF- $\alpha$, IL-6, 
and IL-1 $1 \beta$ in knee joints and serum were inhibited. In another study, HA-NPs were used for delivery of $\gamma$-secretase inhibitor ( $N$-[N-(3,5-difluorophenacetyl)-L-alanyl]-S-phenylglycine $t$-butyl ester [DAPT]) for therapy of inflamed joint of the CIA mice. ${ }^{79}$ The results revealed that DAPT-HA-NPs led to reduction in the clinical scores, tissue damage, and neutrophil infiltration along with the production of pro-inflammatory cytokines (TNF- $\alpha$, IFN- $\gamma$, MCP-1, and IL-6, -12, -17). In an in vitro model of RA, the polysialic acid-trimethyl chitosan NPs were used for delivery of dexamethasone and MTX ${ }^{80}$ These NPs were found to be equally effective as the free drugs. Theranostic polyethyleneimine (PEI)-superparamagnetic iron oxide NPs have also been used for the systemic delivery of IL-2/IL-15R $\beta$-siRNA to arthritic rats. ${ }^{81}$ PEI-SPIO-delivered siRNA accumulated easily in inflamed joints and was efficiently taken up by joint macrophages and T cells. In another study, tranilast (TL) NP- (an anti-allergic agent) based gel ointment was tested on inflammation in adjuvant-induced arthritis rats. ${ }^{82}$ It was observed that the TL concentrations were higher in the skin tissue and the plasma of the rats that were receiving the TL nano gel ointment when compared with the rats that were treated with the TL micro gel ointment. The TL nano gel ointment-treated rats also showed an increase in the paw edema of the hind feet of adjuvant-induced arthritis rats, which was not observed in the case on TL micro gel ointment. Chitosan NPs have been used for delivery of anti-TNF- $\alpha$ siRNA. ${ }^{83}$ Downregulation of TNF- $\alpha$-induced inflammatory responses by these NPs led to inhibition of joint swelling in CIA mice also leading to minimal cartilage destruction and inflammatory cell infiltration in mice. Modified forms of CS such as thiolated glycol chitosan NPs have also been used for delivery of polymerized siRNA targeting TNF- $\alpha^{84}$ for the treatment of RA. Other polymer-based self-assembling NPs such as cyclodextrin NPs for delivery of $\alpha$-methylprednisolone ${ }^{85}$ have also been used intravenously to treat mice with CIA.

There are several nanoformulations that have been used against OA. Hybrid HA/CS NPs have been used as non-viral gene delivery vehicle in rabbit cartilage cells. The HA/CSplasmid NPs showed a significantly higher transfection efficiency than CS-plasmid NPs without lowering the viability of transfected cells. ${ }^{86}$ Similarly a CS-graft-PEI (CP)/DNA NPs have also been used as non-viral gene vectors in both chondrocytes and synoviocytes. The CS-graft-PEI copolymers efficiently carried the pDNA inside chondrocytes and synoviocytes without lowering the cell viability. ${ }^{87}$ Diacereinloaded SLNs modified with chondroitin sulfate $(\mathrm{ChS})$ have also been used in chemically induced rat model for OA was used for the study. It was observed that the presence of drug in joints was higher in rats fed on NP diet when compared with the free drug. ${ }^{88}$ Other NPs that have been synthesized for OA therapy include selenium-ChS NPs. ${ }^{89}$

The above-mentioned studies reveal the success of nanoformulations in arthritis treatment. Most of these nanoformulations were based on CS or derivatives of CS, suggesting that nanoformulations based on CS may achieve desired efficacy in RA. Most of these NPs were able to show high accumulation at the arthritic joint sites when given intravenously or orally. However, they also resulted in large accumulations in liver and spleen. Natural agents such as Fe-bLf and curcumin do not have long-term cytotoxic effects on any body tissues $;{ }^{75-77}$ however, toxic and side effects of synthetic inhibitors such as MTX and methylprednisolone are commonly known. ${ }^{90,91}$ Yet an even balance between the use of natural therapeutic agents and synthetic inhibitors was also observed, suggesting that the role of natural therapeutics remains under-researched and their mechanisms unexplored. Hence, there arises a growing need for targeted delivery of natural anti-inflammatory therapeutics in RA.

\section{Targeted NP approach in RA}

There have been very few attempts in the field of targeted delivery of anti-inflammatory agents in RA (Figure 3) and most of the studies have under-achieved in terms of diseasespecific targeting. Few considerable efforts include delivery of MTX using poly(lactic-co-glycolic acid) NPs targeted with antibody against macrophage-specific receptor-CD64 in an in vitro model using RAW 264.7 cells. ${ }^{92}$ It was observed that the MTX-loaded NPs were more effective than the free drug. In another study, delivery of lipase-labile fumagillin prodrug (Fum-PD) was achieved using perfluorocarbon targeted with $\alpha v \beta 3$-integrin peptidomimetic antagonists. ${ }^{93,94}$ Fum-PD nanotherapy induces the production of endothelial nitric oxide by which it indirectly suppresses inflammation in experimental RA. Tocilizumab-loaded hyaluronate-gold nanoparticles targeted with a monoclonal antibody against IL-6 have also been tested in CIA mice. ${ }^{95}$ In another study, the delivery of MTX was achieved using theranostic gold half-shell NPs targeted with RGD peptides. ${ }^{96}$ It was revealed that a much smaller dose of these NPs showed greater therapeutic effects than that of a conventional treatment with MTX solution in CIA mice. Poly(lactic-co-glycolic acid) NPs targeted with RGD peptides have also been used for STAT1 siRNA delivery, where the presence of RGD peptide on the NPs increased paw tissue uptake in arthritic 


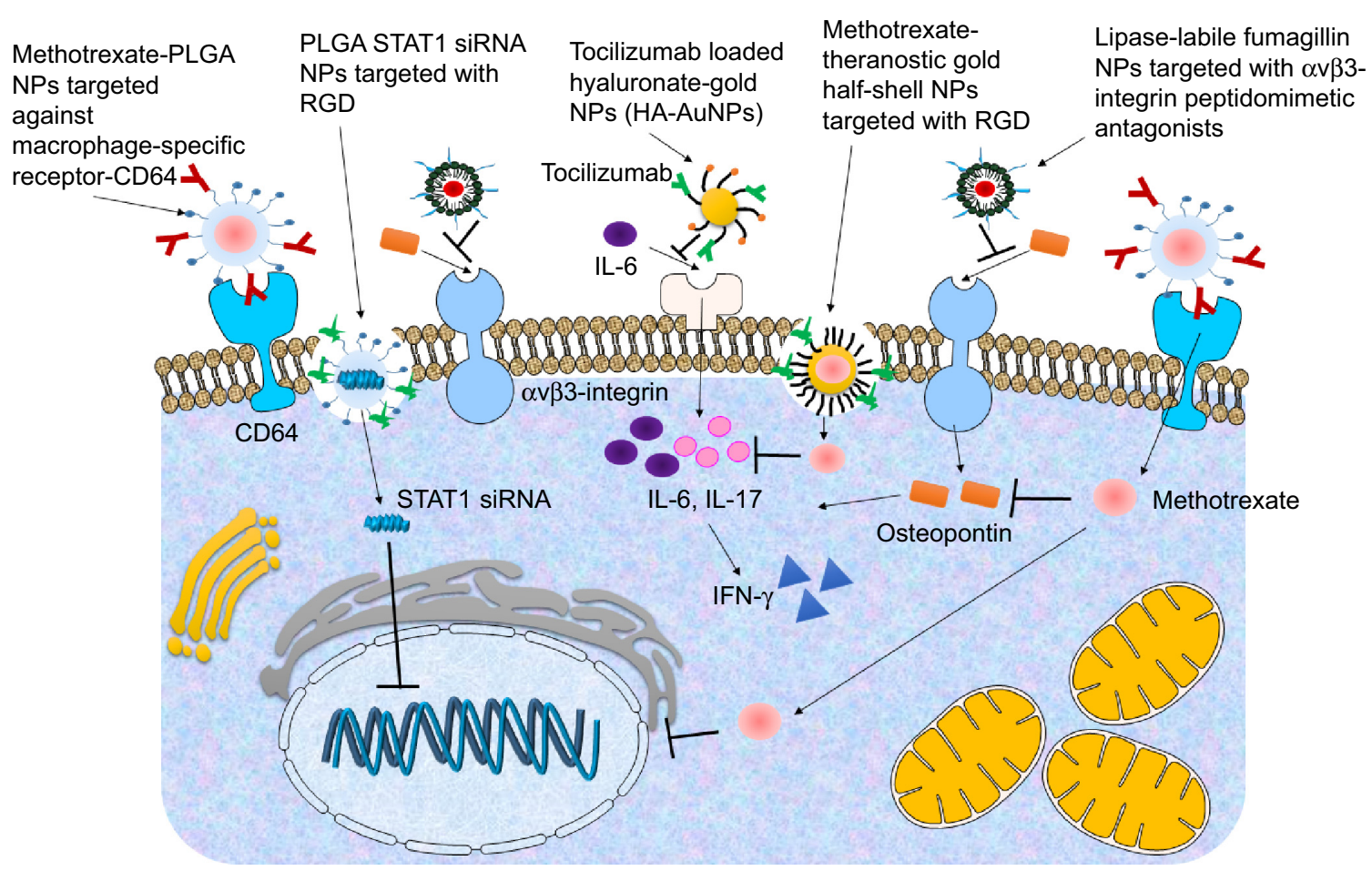

Figure 3 Targeted nanoparticle (NP) approach in rheumatoid arthritis.

Notes: Diagrammatic representation of key targeted NP approaches in treatment of rheumatoid arthritis. The NPs used so far include poly(lactic-co-glycolic acid) (PLGA) NPs targeted with antibody against macrophage-specific receptor-CD64, lipase-labile fumagillin (Fum-PD) was achieved using perfluorocarbon targeted with $\alpha v \beta 3$-integrin peptidomimetic antagonists, tocilizumab (TCZ) loaded HA-AuNPs targeted with monoclonal antibody against interleukin-6 (IL-6), Methotrexate (MTX) loaded theranostic gold $(\mathrm{Au})$ half-shell NPs targeted with arginine-glycine-aspartate (RGD) peptides and PLGA NPs targeted with RGD peptides for STATI siRNA delivery.

mice. Furthermore, RGD functionalization increased lung delivery of NPs in arthritic mice but not in control mice. STAT1 was silenced leading to an increase in expression of Mrc-1 and IL-10 mRNA. ${ }^{97}$

The above-mentioned studies have used antibodies, synthetic peptidomimetics, or RGD peptides for targeting. However, immunogenic effects of antibodies are well known, ${ }^{98}$ cytotoxicity issues and safety issues of peptidomimetics are not yet established and RGD peptides are not specific against any rheumatoid markers. Hence, there are major drawbacks with most of these studies. Very few of these studies have used biodegradable and safe nanocarriers and even though the success of CS has been well established using non-targeted NPs, no attempts have been made so far for targeting CS or CS-derived NPs in RA model. Therefore, a significant gap of knowledge remains yet to be fulfilled as much remains unexplored in the field of targeted delivery toward RA.

\section{Conclusion and future perspective}

Side effects of synthetic drugs and inhibitors can be reduced to a certain extent; however, they cannot be completely avoided due to toxic drugs. Therefore, the current focus has shifted toward natural therapeutics (Figure 4). Bovine lactoferrin is one such naturally derived anti-inflammatory protein that has the ability to suppress the inflammation by multiple ways. Lactoferrin is reported to downregulate the allergic inflammations by inhibiting the Th1 Treg cells. ${ }^{99}$ Hence, lactoferrin also controls the serum cytokine levels and has been reported to significantly lower the serum concentrations of pro-inflammatory cytokines TNF- $\alpha$ and IL-6. ${ }^{100}$ Apart from reducing the pro-inflammatory cytokines, lactoferrin is also known to induce expression of antiinflammatory cytokines. ${ }^{101}$ Human mesenchymal stem cells (MSCs) are defined by their capacity to differentiate into bone, cartilage, and adipose tissue, depending on the stimuli and are found in vivo in low frequency. These MSCs are very critical as therapeutics as they regulate the immune response invoked in settings such as tissue injury, transplantation, and autoimmunity. ${ }^{102}$ Integrins and CD44 are common markers of MSCs. ${ }^{103}$ Lactoferrin is known to effectively downregulate CD44 and other integrins. ${ }^{104}$ Lactoferrin is known to induce proliferation of chondroprogenitor cells in the initial stage of differentiation by upregulating Smad2/3-Sox 9 signaling pathway and inhibits hypertrophic differentiation of chondrocytes induced by aggrecan synthesis and $\mathrm{N}$-cadherin expression. ${ }^{105}$ Lactoferrin is also reported to have the ability to revive the 


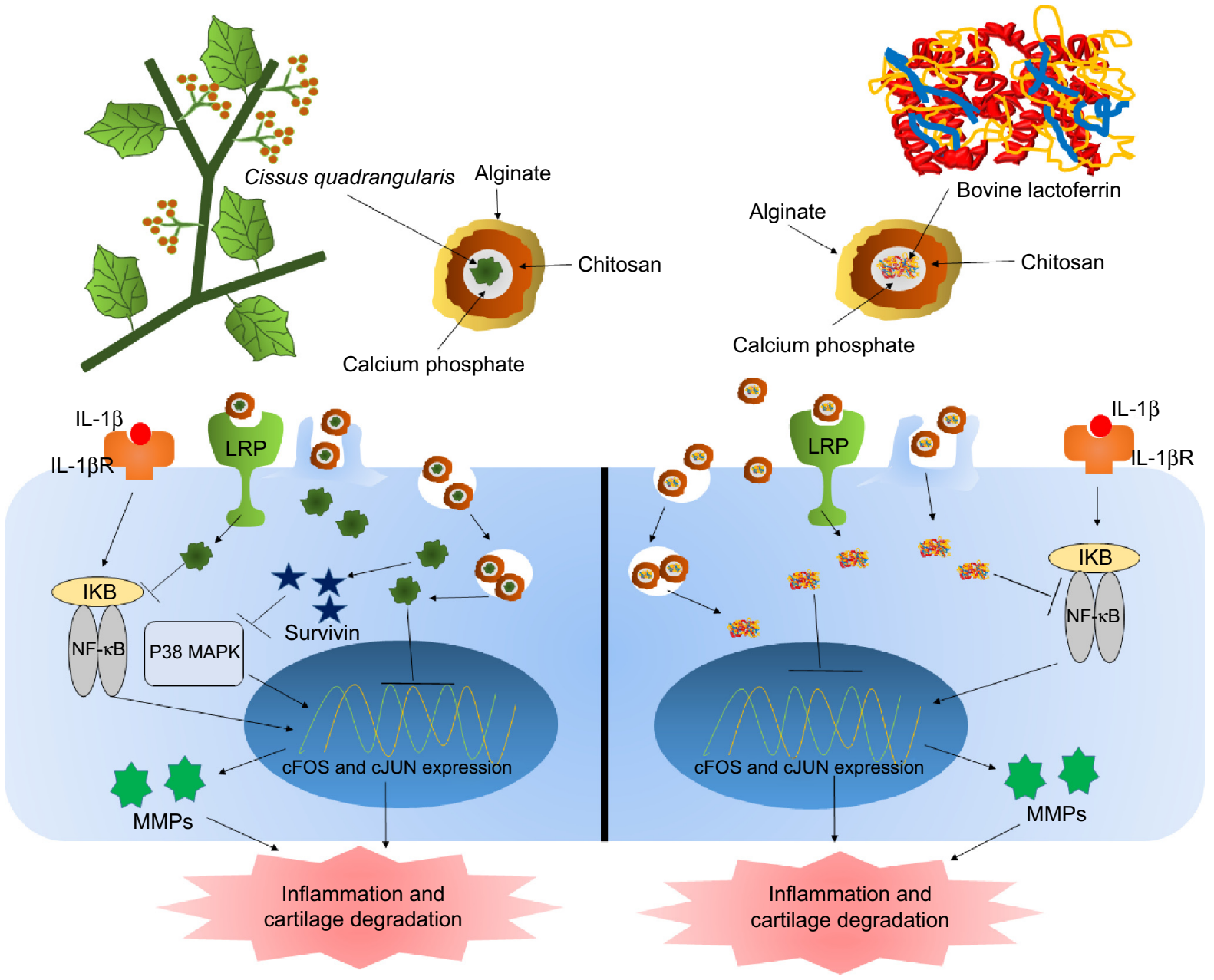

Figure 4 Natural therapy for arthritis using alginate-enclosed chitosan-coated calcium phosphate nanoparticles (AEC-CP-NCs).

Notes: Cissus quadrangularis inhibits catabolic activity of IL-I $\beta$-induced inflammation and cartilage damage. Reduction of pro-inflammatory cytokines and MMPs are also regulated by treatment of $C$. quadrangularis. Fe-bLf, on the other hand, inhibits the activation of inflammatory and cartilage degenerative genes and proteins as well as miRNA involved in depleting iron and calcium metabolism. AEC-CP-NCs are readily absorbed by intestinal cells due to its mucoadhesive nature and are taken up by the circulation where they reach disease inflamed arthritic joints by the enhanced permeability and retention (EPR) effect. NCs internalize by endocytosis and receptor-mediated endocytotic pathways.

Abbreviations: Fe-bLf, iron saturated bovine lactoferrin; IL, interleukin; MMPs, matrix metalloproteinase; NCs, nanocarriers.

proliferation potential of drug-impaired chondrocytes. ${ }^{106}$ Lactoferrin has also been considered as a bone growth factor as it stimulates the proliferation and differentiation of osteoblasts and acts as a survival factor inhibiting their apoptosis. ${ }^{107}$ Deposition and accumulation of calcium pyrophosphate in the knee joints and the SF is linked with deterioration of knee health and progression of RA. ${ }^{108}$ Calcium pyrophosphate crystals are known to induce expression of pro-inflammatory cytokine such as TNF- $\alpha .{ }^{109}$ Lactoferrin has the ability to dissolve these crystals and prevents their accumulation in the joints and in $\mathrm{SF} ;{ }^{75}$ therefore, prevents expression of pro-inflammatory cytokines, degradation of cartilage, and progression of RA.

Targeted nanodelivery of therapeutics has achieved a fair bit of success; however, not many biodegradable and safe polymeric particles have been explored. The potential of locked nucleic acids and oligonucleotides aptamers also remains vastly unexplored. Hence, in spite of years of research and development of several promising strategies there are several domains yet to be fully explored in arthritis research in order to find a suitable and appropriate cure.

\section{Acknowledgments}

The authors would like to thank the Australia-India Strategic Research Fund (AISRF, BF030016) and National Health and Medical Research Council (NHMRC, APP1050286) for providing the funding for this project.

\section{Disclosure}

The authors report no conflicts of interest in this work. 


\section{References}

1. Lawrence RC, Helmick CG, Arnett FC, et al. Estimates of the prevalence of arthritis and selected musculoskeletal disorders in the United States. Arthritis Rheumatol. 1998(41):778-799.

2. Cross M, Smith E, Hoy D, et al. The global burden of rheumatoid arthritis: estimates from the Global Burden of Disease 2010 study. Ann Rheum Dis. 2014;73(7):1316-1322.

3. van der Heijde D, Tanaka Y, Fleischmann R, et al. Tofacitinib (CP-690,550) in patients with rheumatoid arthritis receiving methotrexate: twelve-month data from a twenty-four-month phase III randomized radiographic study. Arthritis Rheum. 2013;65(3):559-570.

4. Fleischmann R, Kremer J, Cush J, et al. Placebo-controlled trial of tofacitinib monotherapy in rheumatoid arthritis. New Engl J Med.2012; 367(6):495-507.

5. Dowty ME, Jesson MI, Ghosh S, et al. Preclinical to clinical translation of tofacitinib, a Janus kinase inhibitor, in rheumatoid arthritis. J Pharmacol Exp Ther. 2014;348(1):165-173.

6. Riese RJ, Krishnaswami S, Kremer J. Inhibition of JAK kinases in patients with rheumatoid arthritis: scientific rationale and clinical outcomes. Best Pract Res Clin Rheumatol. 2010;24(4):513-526.

7. Rajagopalan PR, Zhang Z, McCourt L, Dwyer M, Benkovic SJ, Hammes GG. Interaction of dihydrofolate reductase with methotrexate: ensemble and single-molecule kinetics. Proc Natl Acad Sci. 2002; 99(21):13481-13486.

8. Wessels J, Huizinga T, Guchelaar H-J. Recent insights in the pharmacological actions of methotrexate in the treatment of rheumatoid arthritis. Rheumatology. 2008;47(3):249-255.

9. Brody M, Böhm I, Bauer R. Mechanism of action of methotrexate: experimental evidence that methotrexate blocks the binding of interleukin $1 \beta$ to the interleukin 1 receptor on target cells. Clin Chem Lab Med. 1993;31(10):667-674.

10. Weisman MH, Furst DE, Park GS, et al. Risk genotypes in folatedependent enzymes and their association with methotrexate-related side effects in rheumatoid arthritis. Arthritis Rheum. 2006;54(2):607-612.

11. To H, Yoshimatsu H, Tomonari M, et al. Methotrexate chronotherapy is effective against rheumatoid arthritis. Chronobiol Int. 2011;28(3): 267-274.

12. Cronstein BN, Naime D, Ostad E. The antiinflammatory mechanism of methotrexate. Increased adenosine release at inflamed sites diminishes leukocyte accumulation in an in vivo model of inflammation. $J$ Clin Invest. 1993;92(6):2675.

13. Tekeoglu I, Dogan A, Ediz L, Budancamanak M, Demirel A. Effects of thymoquinone (volatile oil of black cumin) on rheumatoid arthritis in rat models. Phytother Res. 2007;21(9):895-897.

14. Endale M, Lee WM, Kwak Y-S, et al. Torilin ameliorates type II collagen-induced arthritis in mouse model of rheumatoid arthritis. Int Immunopharmacol. 2013;16(2):232-242.

15. Barich LL, Schwarz J, Barich D. Oral methotrexate in mice: a cocarcinogenic as well as an anti-tumor agent to methylcholanthreneinduced cutaneous tumors. J Invest Dermatol. 1962;39(6):615-620.

16. Dougados M, Emery P, Lemmel E, Zerbini C, Brin S, van Riel P. When a DMARD fails, should patients switch to sulfasalazine or add sulfasalazine to continuing leflunomide? Ann Rheum Dis. 2005;64(1):44-51.

17. Teschner S, Burst V. Leflunomide: a drug with a potential beyond rheumatology. Immunotherapy. 2010;2(5):637-650.

18. Kalia S, Dutz JP. New concepts in antimalarial use and mode of action in dermatology. Dermatol Ther. 2007;20(4):160-174.

19. Fox RI. Mechanism of action of hydroxychloroquine as an antirheumatic drug. Semin Arthritis Rheum. 1993;23(2 Suppl 1):82-91.

20. Yang L, Zhang J, Wang G. The effect of sodium hyaluronate treating knee osteoarthritis on synovial fluid interleukin- $1 \beta$ and clinical treatment mechanism. Pak J Pharm Sci. 2015;28(1):407-410.

21. Baici A, Lang A, Hörler D, Kissling R, Merlin C. Cathepsin B in osteoarthritis: cytochemical and histochemical analysis of human femoral head cartilage. Ann Rheum Dis. 1995;54(4):289-297.

22. Burrage PS, Mix KS, Brinckerhoff CE. Matrix metalloproteinases: role in arthritis. Front Biosci. 2006;11(1):529-543.
23. Feng Z, Lian K. Identification of genes and pathways associated with osteoarthritis by bioinformatics analyses. Eur Rev Med Pharmacol Sci. 2015;19(5):736-744.

24. Oliviero F, Scanu A, Ramonda R, et al. IL-1 $\beta$ and IL-8 are scavenged by the hexadecylamide derivative of hyaluronic acid: a new mechanism. J Biomed Mater Res A. 2015. doi:10.1002/jbm.a.35422.

25. Kikuchi J, Hashizume M, Kaneko Y, Yoshimoto K, Nishina N, Takeuchi T. Peripheral blood CD4(+)CD25(+)CD127(low) regulatory T cells are significantly increased by tocilizumab treatment in patients with rheumatoid arthritis: increase in regulatory $\mathrm{T}$ cells correlates with clinical response. Arthritis Res Ther. 2015;17(1):10. doi:10.1186/s13075-015-0526-4.

26. Hirota K, Yoshitomi H, Hashimoto M, et al. Preferential recruitment of CCR6-expressing Th17 cells to inflamed joints via CCL20 in rheumatoid arthritis and its animal model. J Exp Med. 2007;204(12):2803-2812.

27. Paulissen SM, van Hamburg JP, Dankers W, Lubberts E. The role and modulation of CCR6+ Th17 cell populations in rheumatoid arthritis. Cytokine. 2015;S1043-S4666(15):57-65.

28. Chen L, Li D, Zhong J, et al. IL-17RA aptamer-mediated repression of IL-6 inhibits synovium inflammation in a murine model of osteoarthritis. Osteoarthritis Cartilage. 2011;19(6):711-718.

29. Ziolkowska M, Koc A, Luszczykiewicz G, et al. High levels of IL-17 in rheumatoid arthritis patients: IL-15 triggers in vitro IL-17 production via cyclosporin A-sensitive mechanism. J Immunol. 2000;164(5): 2832-2838.

30. Fischer JA, Hueber AJ, Wilson S, et al. Combined inhibition of tumor necrosis factor $\alpha$ and interleukin-17 as a therapeutic opportunity in rheumatoid arthritis: development and characterization of a novel bispecific antibody. Arthritis Rheumatol. 2015;67(1):51-62.

31. Thornton S, Raghu H, Jone A, et al. Mice deficient in urokinase-type plasminogen activator (uPA) or uPA receptor develop significantly diminished collagen-induced arthritis. Blood. 2014;124(21):580-580.

32. Rhodes A, Deakin A, Spaull J, et al. The generation and characterization of antagonist RNA aptamers to human oncostatin M. J Biol Chem. 2000; 275(37):28555-28561.

33. Rousseau J-C, Delmas PD. Biological markers in osteoarthritis. Nat Clin Pract Rheumatol. 2007;3(6):346-356.

34. Mizuno M, Fujisawa R, Kuboki Y. Type I collagen-induced osteoblastic differentiation of bone-marrow cells mediated by collagen- $\alpha 2 \beta 1$ integrin interaction. J Cell Physiol. 2000;184(2):207-213.

35. Dodge GR, Poole AR. Immunohistochemical detection and immunochemical analysis of type II collagen degradation in human normal, rheumatoid, and osteoarthritic articular cartilages and in explants of bovine articular cartilage cultured with interleukin 1. J Clin Invest. 1989;83(2):647.

36. Billinghurst RC, Dahlberg L, Ionescu M, et al. Enhanced cleavage of type II collagen by collagenases in osteoarthritic articular cartilage. J Clin Invest. 1997;99(7):1534.

37. Wang L. Effects of RNAi-mediated inhibition of aggrecanase-1 and aggrecanase-2 on rat costochondral chondrocytes in vitro1. Acta Pharmacol Sin. 2008;29(10):1215-1226.

38. Wang ZH, Yang ZQ, He XJ, Kamal BE, Xing Z. Lentivirus-mediated knockdown of aggrecanase-1 and-2 promotes chondrocyte-engineered cartilage formation in vitro. Biotechnol Bioeng. 2010;107(4):730-736.

39. Place LW, Sekyi M, Kipper MJ. Aggrecan-mimetic, glycosaminoglycancontaining nanoparticles for growth factor stabilization and delivery. Biomacromolecules. 2014;15(2):680-689.

40. Takayanagi H, Oda H, Yamamoto S, et al. A new mechanism of bone destruction in rheumatoid arthritis: synovial fibroblasts induce osteoclastogenesis. Biochem Biophys Res Commun. 1997;240(2):279-286.

41. Gough A, Sambrook P, Devlin J, et al. Osteoclastic activation is the principal mechanism leading to secondary osteoporosis in rheumatoid arthritis. J Rheumatol. 1998;25(7):1282-1289.

42. Dequeker J, Maenaut K, Verwilghen J, Westhovens R. Osteoporosis in rheumatoid arthritis. Clin Exp Rheumatol. 1994;13:S21-S26.

43. Robinson D, Tashjian Jr A, Levine L. Prostaglandin-stimulated bone resorption by rheumatoid synovia. A possible mechanism for bone destruction in rheumatoid arthritis. J Clin Invest. 1975;56(5): 1181. 
44. Monte K, Wilson C, Shih FF. Increased number and function of FoxP3 regulatory $\mathrm{T}$ cells during experimental arthritis. Arthritis Rheum. 2008;58(12):3730-3741

45. Komatsu N, Okamoto K, Sawa S, et al. Pathogenic conversion of Foxp3+ T cells into TH17 cells in autoimmune arthritis. Nat Med. 2014; 20(1):62-68.

46. Banham AH, Pulford K. Therapeutic targeting of FOXP3-positive regulatory $\mathrm{T}$ cells using a FOXP3 peptide vaccine WO2008081581. Expert Opin Ther Pat. 2009;19(7):1023-1028.

47. Gil-Guerrero L, Dotor J, Huibregtse IL, et al. In vitro and in vivo down-regulation of regulatory $\mathrm{T}$ cell activity with a peptide inhibitor of TGF-ß1. J Immunol. 2008;181(1):126-135.

48. Casares N, Rudilla F, Arribillaga L, et al. A peptide inhibitor of FOXP3 impairs regulatory $\mathrm{T}$ cell activity and improves vaccine efficacy in mice. J Immunol. 2010;185(9):5150-5159.

49. Beier UH, Wang L, Bhatti TR, et al. Sirtuin-1 targeting promotes Foxp3+ T-regulatory cell function and prolongs allograft survival. Mol Cell Biol. 2011;31(5):1022-1029.

50. Castor CW. The microscopic structure of normal human synovial tissue. Arthritis Rheum. 1960;3(2):140-151.

51. Kiener HP, Baghestanian M, Dominkus M, et al. Expression of the C5a receptor (CD88) on synovial mast cells in patients with rheumatoid arthritis. Arthritis Rheum. 1998;41(2):233-245.

52. Hueber AJ, Asquith DL, Miller AM, et al. Cutting edge: mast cells express IL-17A in rheumatoid arthritis synovium. J Immunol. 2010; 184(7):3336-3340.

53. Xu G, Nie H, Li N, et al. Role of osteopontin in amplification and perpetuation of rheumatoid synovitis. J Clin Invest. 2005;115(4):1060-1067.

54. Yamamoto N, Sakai F, Kon S, et al. Essential role of the cryptic epitope SLAYGLR within osteopontin in a murine model of rheumatoid arthritis. J Clin Invest. 2003;112(2):181-188.

55. Gravallese EM. Osteopontin: a bridge between bone and the immune system. J Clin Invest. 2003;112(2):147-149.

56. Chen J, Singh K, Mukherjee BB, Sodek J. Developmental expression of osteopontin (OPN) mRNA in rat tissues: evidence for a role for OPN in bone formation and resorption. Matrix. 1993;13(2):113-123.

57. Liaw L, Birk DE, Ballas CB, Whitsitt JS, Davidson JM, Hogan B. Altered wound healing in mice lacking a functional osteopontin gene (spp1). J Clin Invest. 1998;101(7):1468.

58. O'Brien ER, Garvin MR, Stewart DK, et al. Osteopontin is synthesized by macrophage, smooth muscle, and endothelial cells in primary and restenotic human coronary atherosclerotic plaques. Arterioscl Thromb. 1994;14(10):1648-1656.

59. Wesson JA, Johnson RJ, Mazzali M, et al. Osteopontin is a critical inhibitor of calcium oxalate crystal formation and retention in renal tubules. J Am Soc Nephrol. 2003;14(1):139-147.

60. Sennels H, Sørensen S, Østergaard M, et al. Circulating levels of osteopontin, osteoprotegerin, total soluble receptor activator of nuclear factorkappa B ligand, and high-sensitivity C-reactive protein in patients with active rheumatoid arthritis randomized to etanercept alone or in combination with methotrexate. Scand J Rheumatol. 2008;37(4):241-247.

61. Chen G, Zhang X, Li R, et al. Role of osteopontin in synovial Th17 differentiation in rheumatoid arthritis. Arthritis Rheum. 2010;62(10): 2900-2908.

62. Katagiri YU, Sleeman J, Fujii H, et al. CD44 variants but not CD44s cooperate with $\beta 1$-containing integrins to permit cells to bind to osteopontin independently of arginine-glycine-aspartic acid, thereby stimulating cell motility and chemotaxis. Cancer Res. 1999;59(1):219-226.

63. Petrow PK, Hummel KM, Schedel J, et al. Expression of osteopontin messenger RNA and protein in rheumatoid arthritis: effects of osteopontin on the release of collagenase 1 from articular chondrocytes and synovial fibroblasts. Arthritis Rheum. 2000;43(7):1597-1605.

64. Yumoto K, Ishijima M, Rittling SR, et al. Osteopontin deficiency protects joints against destruction in anti-type II collagen antibody-induced arthritis in mice. Proc Natl Acad Sci US A. 2002;99(7):4556-4561.

65. Cheng C, Gao S, Lei G. Association of osteopontin with osteoarthritis. Rheumatol Int. 2014:34(12):1627-1631.
66. Xu M, Zhang L, Zhao L, et al. Phosphorylation of osteopontin in osteoarthritis degenerative cartilage and its effect on matrix metalloprotease 13. Rheumatol Int. 2013;33(5):1313-1319.

67. Iwadate H, Kobayashi H, Kanno T, et al. Plasma osteopontin is correlated with bone resorption markers in rheumatoid arthritis patients. Int J Rheum Dis. 2014;17(1):50-56.

68. Gao S, Li K, Zeng K, Tu M, Xu M, Lei G. Elevated osteopontin level of synovial fluid and articular cartilage is associated with disease severity in knee osteoarthritis patients. Osteoarthritis Cartilage. 2010;18(1): 82-87.

69. Wiesenthal A, Hunter L, Wang S, Wickliffe J, Wilkerson M. Nanoparticles: small and mighty. Int J Dermatol. 2011;50(3):247-254.

70. Gallelli L, Galasso O, Falcone D, et al. The effects of nonsteroidal anti-inflammatory drugs on clinical outcomes, synovial fluid cytokine concentration and signal transduction pathways in knee osteoarthritis. A randomized open label trial. Osteoarthritis Cartilage. 2013;21(9): 1400-1408.

71. Radad K, Al-Shraim M, Moldzio R, Rausch W-D. Recent advances in benefits and hazards of engineered nanoparticles. Environ Toxicol Pharmacol. 2012;34(3):661-672.

72. Cooper ER. Nanoparticles: a personal experience for formulating poorly water soluble drugs. J Control Release. 2010;141(3):300-302.

73. Zolnik BS, Gonzalez-Fernandez A, Sadrieh N, Dobrovolskaia MA. Minireview: nanoparticles and the immune system. Endocrinology. 2010;151(2):458-465.

74. Sanvicens N, Marco MP. Multifunctional nanoparticles-properties and prospects for their use in human medicine. Trends Biotechnol. 2008; 26(8):425-433.

75. Samarasinghe RM, Kanwar RK, Kanwar JR. The effect of oral administration of iron saturated-bovine lactoferrin encapsulated chitosan-nanocarriers on osteoarthritis. Biomaterials. 2014;35(26):7522-7534.

76. Samarasinghe RM, Kanwar RK, Kumar K, Kanwar JR. Antiarthritic and chondroprotective activity of Lakshadi Guggul in novel alginateenclosed chitosan calcium phosphate nanocarriers. Nanomedicine. 2014;9(6):819-837.

77. Arora R, Kuhad A, Kaur I, Chopra K. Curcumin loaded solid lipid nanoparticles ameliorate adjuvant-induced arthritis in rats. Eur J Pain. 2014;19(7):940-952. doi:10.1002/ejp.620.

78. Babazada H, Yamashita F, Hashida M. Suppression of experimental arthritis with self-assembling glycol-split heparin nanoparticles via inhibition of TLR4-NF-кB signaling. J Control Release. 2014;194: 295-300.

79. Heo R, Park J-S, Jang HJ, et al. Hyaluronan nanoparticles bearing $\gamma$-secretase inhibitor: In vivo therapeutic effects on rheumatoid arthritis. J Control Release. 2014;192:295-300.

80. Zhang N, Wardwell PR, Bader RA. In vitro efficacy of polysaccharidebased nanoparticles containing disease-modifying antirheumatic drugs. Pharm Res. 2014;31(1-9):2326-2334

81. Duan J, Dong J, Zhang T, et al. Polyethyleneimine-functionalized iron oxide nanoparticles for systemic siRNA delivery in experimental arthritis. Nanomedicine. 2014;9(7):789-801.

82. Nagai N, Ito Y. Therapeutic effects of gel ointments containing tranilast nanoparticles on paw edema in adjuvant-induced arthritis rats. Biol Pharm Bull. 2014;37(1):96-104.

83. Howard KA, Paludan SR, Behlke MA, Besenbacher F, Deleuran B, Kjems J. Chitosan/siRNA nanoparticle-mediated TNF- $\alpha$ knockdown in peritoneal macrophages for anti-inflammatory treatment in a murine arthritis model. Mol Ther. 2008;17(1):162-168.

84. Lee SJ, Lee A, Hwang SR, et al. TNF- $\alpha$ Gene silencing using polymerized siRNA/thiolated glycol chitosan nanoparticles for rheumatoid arthritis. Mol Ther. 2013;22(2):397-408.

85. Hwang J, Rodgers K, Oliver JC, Schluep T. $\alpha$-Methylprednisolone conjugated cyclodextrin polymer-based nanoparticles for rheumatoid arthritis therapy. Int J Nanomed. 2008;3(3):359.

86. Lu H-D, Zhao H-Q, Wang K, Lv L-L. Novel hyaluronic acid-chitosan nanoparticles as non-viral gene delivery vectors targeting osteoarthritis. Int J Pharm. 2011;420(2):358-365. 
87. Lu H, Dai Y, Lv L, Zhao H. Chitosan-graft-polyethylenimine/DNA nanoparticles as novel non-viral gene delivery vectors targeting osteoarthritis. PLoS One. 2014;9(1):e84703.

88. Jain A, Mishra SK, Vuddanda PR, Singh SK, Singh R, Singh S. Targeting of diacerein loaded lipid nanoparticles to intra-articular cartilage using chondroitin sulfate as homing carrier for treatment of osteoarthritis in rats. Nanomedicine. 2014;10(5):1031-1040.

89. Han J, Guo X, Lei Y, Dennis BS, Wu S, Wu C. Synthesis and characterization of selenium-chondroitin sulfate nanoparticles. Carbohydr Polym. 2012;90(1):122-126.

90. Bannwarth B, Schaeverbeke T, Labat L, Marce S, Demotes-Mainard F, Dehais J. [Side-effects during treatment of rheumatoid arthritis with methotrexate]. Rev Rhum Ed Fr. 1994;61(5):337-342.

91. Gutkowski K, Chwist A, Hartleb M. Liver injury induced by high-dose methylprednisolone therapy: a case report and brief review of the literature. Hepat Mon. 2011;11(8):656.

92. Moura CC, Segundo MA, das Neves J, Reis S, Sarmento B. Coassociation of methotrexate and SPIONs into anti-CD64 antibodyconjugated PLGA nanoparticles for theranostic application. Int J Nanomed. 2014;9(1):4911-4922.

93. Zhou H-f, Yan H, Hu Y, et al. Fumagillin prodrug nanotherapy suppresses macrophage inflammatory response via endothelial nitric oxide. ACS Nano. 2014;8(7):7305-7317.

94. Zhou H-f, Yan H, Senpan A, et al. Suppression of inflammation in a mouse model of rheumatoid arthritis using targeted lipase-labile fumagillin prodrug nanoparticles. Biomaterials. 2012;33(33):8632-8640.

95. Lee H, Lee M-Y, Bhang SH, et al. Hyaluronate-gold nanoparticle/ tocilizumab complex for the treatment of rheumatoid arthritis. ACS Nano. 2014;8(5):4790-4798.

96. Lee S-M, Kim HJ, Ha Y-J, et al. Targeted chemo-photothermal treatments of rheumatoid arthritis using gold half-shell multifunctional nanoparticles. ACS Nano. 2012;7(1):50-57.

97. Scheinman RI, Trivedi R, Vermillion S, Kompella UB. Functionalized STAT1 siRNA nanoparticles regress rheumatoid arthritis in a mouse model. Nanomedicine. 2011;6(10):1669-1682.

98. Harding FA, Stickler MM, Razo J, DuBridge RB. The immunogenicity of humanized and fully human antibodies: residual immunogenicity resides in the CDR regions. MAbs. 2010;2(3):256-265.
99. Wang SB, Deng YQ, Ren J, Xiao BK, Chen Z, Tao ZZ. Lactoferrin administration into the nostril alleviates murine allergic rhinitis and its mechanisms. Scand J Immunol. 2013;78(6):507-515.

100. Machnicki M, Zimecki M, Zagulski T. Lactoferrin regulates the release of tumour necrosis factor alpha and interleukin 6 in vivo. Int $J \operatorname{Exp}$ Pathol. 1993;74(5):433-439.

101. Valenti P, Catizone A, Pantanella F, et al. Lactoferrin decreases inflammatory response by cystic fibrosis bronchial cells invaded with Burkholderia cenocepacia iron-modulated biofilm. Int J Immunopathol Pharmacol. 2010;24(4):1057-1068.

102. Singer NG, Caplan AI. Mesenchymal stem cells: mechanisms of inflammation. Annu Rev Pathol. 2011;6:457-478.

103. Lin C-S, Xin Z-C, Dai J, Lue TF. Commonly used mesenchymal stem cell markers and tracking labels: Limitations and challenges. Histol Histopathol. 2013;28(9):1109.

104. Kanwar JR, Mahidhara G, Roy K, et al. Fe-bLf nanoformulation targets survivin to kill colon cancer stem cells and maintains absorption of iron, calcium and zinc. Nanomedicine. 2014;10(1):35-55.

105. Takayama Y, Mizumachi K. Inhibitory effect of lactoferrin on hypertrophic differentiation of ATDC5 mouse chondroprogenitor cells. Biometals. 2010;23(3):477-484.

106. Tu Y, Xue H, Francis W, et al. Lactoferrin inhibits dexamethasoneinduced chondrocyte impairment from osteoarthritic cartilage through up-regulation of extracellular signal-regulated kinase 1/2 and suppression of FASL, FAS, and Caspase 3. Biochem Biophys Res Commun. 2013;441(1):249-255.

107. Cornish J, Callon KE, Naot D, et al. Lactoferrin is a potent regulator of bone cell activity and increases bone formation in vivo. Endocrinology. 2004;145(9):4366-4374.

108. Halverson PB, McCarty DJ. Patterns of radiographic abnormalities associated with basic calcium phosphate and calcium pyrophosphate dihydrate crystal deposition in the knee. Ann Rheum Dis. 1986; 45(7):603-605.

109. Meng Z, Hudson A, Schumacher Jr H, Baker J, Baker D. Monosodium urate, hydroxyapatite, and calcium pyrophosphate crystals induce tumor necrosis factor-alpha expression in a mononuclear cell line. J Rheumatol. 1997;24(12):2385-2388.
International Journal of Nanomedicine

\section{Publish your work in this journal}

The International Journal of Nanomedicine is an international, peerreviewed journal focusing on the application of nanotechnology in diagnostics, therapeutics, and drug delivery systems throughout the biomedical field. This journal is indexed on PubMed Central, MedLine, CAS, SciSearch ${ }^{\circledR}$, Current Contents ${ }^{\circledR} /$ Clinical Medicine,
Dovepress

Journal Citation Reports/Science Edition, EMBase, Scopus and the Elsevier Bibliographic databases. The manuscript management system is completely online and includes a very quick and fair peer-review system, which is all easy to use. Visit http://www.dovepress.com/ testimonials.php to read real quotes from published authors. 